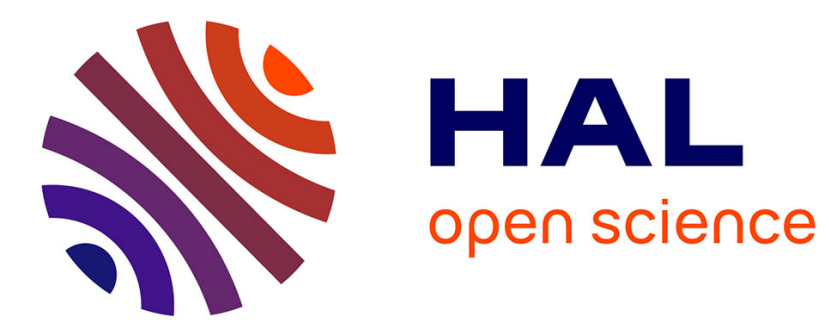

\title{
Exploring Embodied Learning for Early Childhood Education
}

\author{
Marion Voillot, Joël Chevrier, Frédéric Bevilacqua, Claire Eliot
}

\section{To cite this version:}

Marion Voillot, Joël Chevrier, Frédéric Bevilacqua, Claire Eliot. Exploring Embodied Learning for Early Childhood Education. the Interaction Design and Children, Jun 2019, Boise, France. pp.747$750,10.1145 / 3311927.3325347$. hal-02495841

\section{HAL Id: hal-02495841 https://hal.science/hal-02495841}

Submitted on 2 Mar 2020

HAL is a multi-disciplinary open access archive for the deposit and dissemination of scientific research documents, whether they are published or not. The documents may come from teaching and research institutions in France or abroad, or from public or private research centers.
L'archive ouverte pluridisciplinaire HAL, est destinée au dépôt et à la diffusion de documents scientifiques de niveau recherche, publiés ou non, émanant des établissements d'enseignement et de recherche français ou étrangers, des laboratoires publics ou privés. 


\section{Exploring Embodied Learning for Early Childhood Education}

\section{Marion Voillot}

STMS Ircam-CNRS-Sorbonne Université

Paris, France

CRI, Université Paris-Descartes

Paris, France

marion.voillot@ircam.fr

\section{Joël Chevrier}

CRI, Université Paris-Descartes

Paris, France

Université Grenoble-Alpes

Grenoble, France

joel.chevrier@cri-paris.org
Frédéric Bevilacqua

STMS Ircam-CNRS-Sorbonne Université

Paris, France

frederic.bevilacqua@ircam.fr

\section{Claire Eliot}

CRI, Université Paris-Descartes

Paris, France

claire.eliot@cri-paris.org

\section{ABSTRACT}

This PhD project is multidisciplinary, at the intersection of Early Childhood Education, Design, and Human-Computer Interaction. The PhD goal aim at developing new approaches for early childhood education focusing on the role of body in the learning process. We leverage digital tangible and interactive technologies to develop specific scenarios that are evaluated in preschools. Our work proposes novel paradigms and uses of digital technologies currently not found in typical preschool environments.

Permission to make digital or hard copies of part or all of this work for personal or classroom use is granted without fee provided that copies are not made or distributed for profit or commercial advantage and that copies bear this notice and the full citation on the first page. Copyrights for third-party components of this work must be honored. For all other uses, contact the owner/author(s).

CHI'19 Extended Abstracts, May 4-9, 2019, Glasgow, Scotland, UK.

(c) 2019 Copyright is held by the author/owner(s).

ACM ISBN 978-1-4503-5971-9/19/05.

DOI: https://doi.org/10.1145/3290607. 


\section{KEYWORDS}

Early Childhood Education, Screenless

Technology, Tangible Interaction, Motion Sensors,

Pedagogical Design, Embodied Learning

\section{INTRODUCTION}

Digital technology transforms every aspect of our society. Smartphones, tablets and computers have invaded our daily life, and thus children become digital users from an early age. In a sensitive period of development, most of them have already used a smartphone or tablet on their own, they easily appropriate. Even though the children environment becomes digital, schools and especially kindergartens remain hermetic to new technologies.

These constant technological revolution have left teachers somewhat bewildered: they are generally not prepared to this ever changing digital world and do not have methods, tools and environments, to adapt their pedagogy accordingly. Moreover, digital technologies are often perceived in a negative way in early childhood education, in considering digital technologies only as screen interfaces, in front of which children are mostly passive (Nelly Bowles, in NY Times, October 2018). Digital, as it is used in daily life, imposes a paradigm that is not currently compatible with school.

However, other uses are readily possible using embedded sensors (motion, microphone, etc.) of tablets and smartphones, which can encourage body movement, playful learning and knowledge sharing, within the pedagogical environment [2].

\section{RESEARCH QUESTIONS}

The premises of the underlying idea of this $\mathrm{PhD}$ project is to consider digital tools as mobile pedagogical materials The general goal thus, is to develop tangible and movement-based digital technologies to serve the child's development. In the context of active teaching stimulating interactions between young children, families and teachers we promote learning from school to home through technology. The current PhD title summarizes this general aim : How to create a new paradigm placing the body at the heart of learning leveraging digital technology for early childhood education?

To answer this important and complex question, we will first tackle the following points : Can we change our relationship to technology in order to encourage interaction and body movement from an early age ? What can we learn from alternative education for this? And finally, how can we design and create a new pedagogical environment to promote embodied learning (inspired by $\mathrm{HCl}$ ) ?

\section{From Alternative Education to Embodied Learning}

In this PhD project, the theoretical bases are founded on first, Alternative Education and second Human-Computer Interaction and Embodied Interaction.

A young child's development depends on the pedagogical approach used from a very young age, e.g.his education between two and five years old. Early childhood is the fastest and the most complex stage of our development as human beings [11]. 


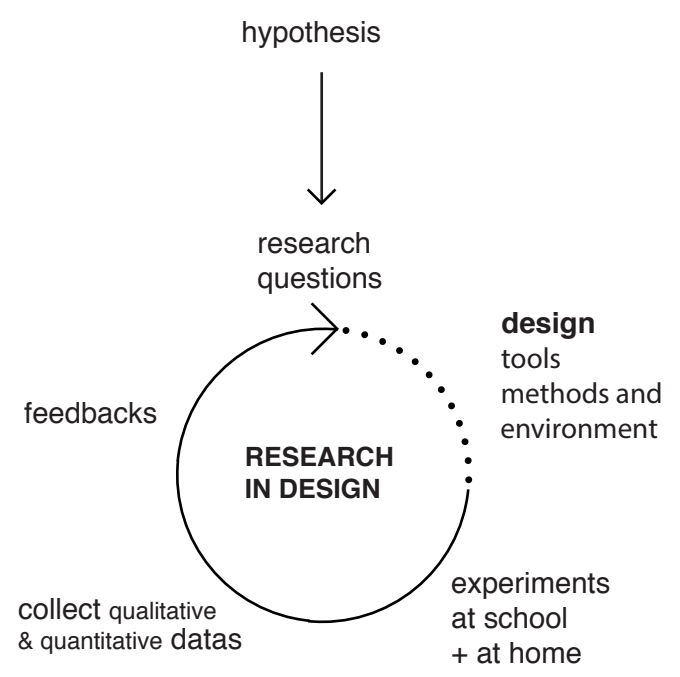

In alternative education, the child is author of his actions, actor of his own learning [10] and is generally opposed to the Cartesian mind-body dualism [6]. These pedagogies highlight body exploration based on educational invariants: perception and psychomotor development, mobility and autonomy, investment and mutual aid, as well as knowledge and understanding of the environment In our project, we consider that the implementation of these pedagogies can be revisited through digital culture. Actually, a recent report from Unesco [8] emphasises the potential value of ICT in terms of children's play and learning, supporting "communication and collaboration, cognitive development, creativity, sociodramatic play and learning to learn".

Enaction [12] and embodied cognition [1] have influenced the field of $\mathrm{HCl}$ that has embraced notion such as embodied interaction [4]. Education and pedagogy are also slowly integrating such concepts. Thea lonescu has proposed a review on Embodied cognition and psychology and education [7]. Recently, Keifert et al. have proposed mixed-reality environment for education in science [9].

\section{RESEARCH METHODOLOGIES}

\section{Mixed Methods approaches}

Our research is design-driven and based on human-centered methodologies: we are collaborating with people who take care for toddlers in health and education, families and parents, as well as designers and engineers. Fig.1

All our scenarios are tested in young children natural environment, supporting an ecological research approach [5]. We also organize workshops with families and parents in our home program "Lab Premiers Cris", which is an "Action-Research Collaboratory on Early Childhood using Digital Technology" based at the CRI in Paris. These experiments allow us to collect qualitative datas such as physical and verbal interactions, relationships, assimilation of tools and quantitative datas gestural learning, assimilation time, speed of gesture among others. The analysis of which will help us measure the impact and benefit of our proposals for early childhood education.

The use of mixed methods approaches in design allow us to build an interdisciplinary community involved in a collaborative research. That appears to be a sustainable solution to strengthen early childhood research according to UNICEF's Programme Guidance For Early Childhood Development.

\section{Interactive Technologies}

We use various technologies developed at IRCAM and CRI, such as gesture recognition using smartphones and motion sensors or electronic-textile devices. By combining these technologies and theoretical bases on alternative education, child's psychology and embodied learning on $\mathrm{HCl}$, we are creating different pedagogical scenarios. 


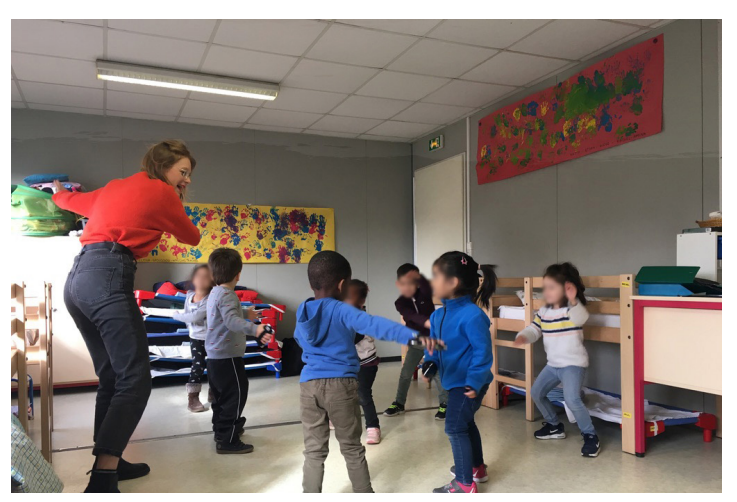

Figure 2 : Scenario of an Interactive Story performed in a kindergarten in Paris with children from 3 to 6 years old

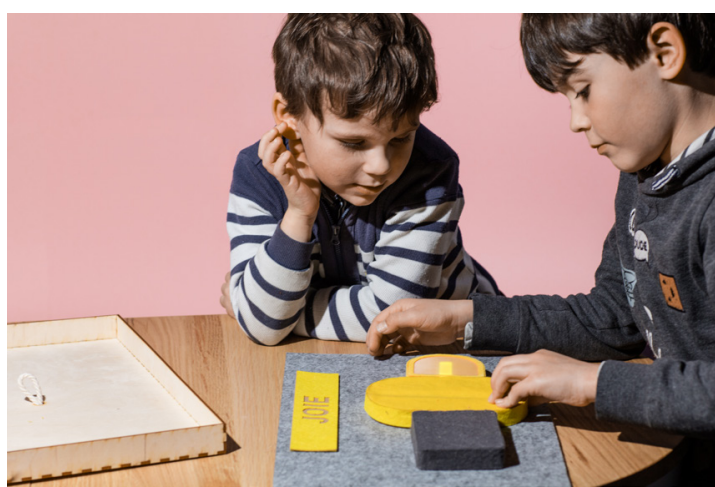

Figure 3: Scenario of Learning Matter - in this case children interact with e-textile to express their emotions

\section{CURRENT ACHIEVEMENTS AND RESULTS}

For the moment, we have developed 2 types of scenarios :

- Interactive story. Fig.2 : In this scenario children are all equipped with smartphones attached to their hands. Throughout the story performed by the teacher, children are invited to imitate specific gestures together. Smartphones then become instruments transforming these gestures into sounds. Thanks to the technology developed at IRCAM, certain type of gestures is automatically recognized and a coherent sound is played (footsteps on the floor, the sound of running water, birds chirping, etc.).

- Learning Matter. Fig.3 : In collaboration with the e-textile designer, Claire Eliot, we have created digital tangible interfaces for toddlers in electronic textile. Each device is composed of several elements integrated in textiles: sensor, light source and battery. First, children are led to assemble the devices in order to learn the basics of electronic circuit. Then, they explore the specific gestures that will put each device into action - stroking, tapping, blowing, shaking, rolling. The feedback invites them to become aware of their sensation (softness, roughness for example) and emotions (tenderness, anger, disappointment among others.)

\section{CONCLUSION}

In summary, by mixing design based research and mixed methods approaches [3], this PhD project highlights the use of tangible and movement-based digital interfaces to empower children, teachers and families. These ecological experiments allow us to collect quantitative and qualitative data and then, define the first principles of an active early childhood education leveraging digital technology.

\section{REFERENCES}

1. Michael L. Anderson. 2003. Embodied cognition: A field guide in Artificial intelligence, vol. 149, 91-130.

2. Frédéric Bevilacqua, Eric O. Boyer, Jules Françoise, Olivier Houix, Patrick Susini, Agnès Roby-Brami, Sylvain Hanneton. 2016. Sensori-motor learning with movement sonification: Perspectives from recent interdisciplinary studies in Frontiers in Neuroscience, 10:385.

3. John W. Creswell. 2003. Research Design. Qualitative, Quantitative and Mixed Methods Approaches. Sage Publications. 4. Paul Dourish. 2004. Where the action is: the foundations of embodied interaction. MIT press.

5. Eleanor J. Gibson, Anne D. Pick. 2000. An Ecological Approach to Perceptual Learning and Development. Oxford University Press, New York.

6. Lisa Hunter. 2004. Movement and the Body in Teaching: Challenging the Commonsense Dualism, Journal for Australian Primary School Leaders, Brisbane, Queensland, Australia.

7. Thea lonescu, Dermina Vasc. 2014. Embodied cognition: challenges for psychology and education in Procedia-Social and Behavioral Sciences, vol. 128, 275-280.

8. Ivan Kalas. 2012. ICTs in Early Childhood Care and Education, Unesco Institute for Information on Technologies in Education 9.Danielle Keifert, Christine Lee, Maggie Dahn, Randy Illum, David DeLiema, Noel Enyedy, Joshua Danish (2017) Agency, Embodiment \& Affect During Play in a Mixed-Reality Learning Environment. In IDC 2017, Stanford, CA, USA.

10. Maria Montessori. 2010. The Absorbent Mind, Holt Paperbacks, New York.

11. Jean Piaget, Inhelder Barbel. 1962. The Psychology of the Child (2nd. ed.) Basic Books, New York.

12. John Stewart, Olivier Gapenne, et al. 2010. Enaction: Toward a new paradigm for cognitive science. MIT Press. 